FACTA UNIVERSITATIS

Series: Economics and Organization Vol. 14, $\mathrm{N}^{\mathrm{o}}$ 2, 2017, pp. 155 - 162

DOI: $10.22190 /$ FUEO1702155D

Preliminary Communication

\title{
APPLICATION OF THE MINCER EARNING FUNCTION IN ANALYZING GENDER PAY GAP IN SERBIA
}

\author{
UDC 331.5:305-055.2
}

\section{Stojanka Dakić, Mirko Savić}

University of Novi Sad, Faculty of Economics, Subotica

\begin{abstract}
Better economic status of women in the labour market and reduction of gender pay gap is an important determinant of economic and social progress of the country. Gender pay gap is one of the key indicators of women's access to economic opportunities and undoubtedly one of the most constant features of the labour market. Failure to comply with the principle of equality and equal opportunities for women and men is considered a violation of basic human rights. As a result there are significant losses in the economy of countries such as loss of business and economic benefits, and insufficient use of available human resources. If there is no economic independence, all other measures taken to improve the position of women in society in general have much less success and influence. The aim of this paper is to determine whether there is a difference between men and women regarding wages. Mincer earnings function according to which individuals' earnings are function of the achieved level of education and work experience, served as the basis for analysis of the factors that determine the formation of wages. For the analysis we have used data collected by the survey EU-SILC in 2014 in Serbia. Regression model was built and confirmed the presence of the gender gap in earnings and the impact of gender on the formation of wages in the context that females earn less than males. Due to the inadequacy of the available data, the height of the gender gap in earnings has not been determined, nor its decomposition done.
\end{abstract}

Key words: gender pay gap, labour market, regression model, EU-SILC.

JEL Classification: J01, J30, J71.

Received April 3, 2017 / Accepted May 10, 2017

Corresponding author: Stojanka Dakić

Faculty of Economics, Segedinski put 9-11, Subotica, Serbia

E-mail: stojankad@ef.uns.ac.rs 


\section{INTRODUCTION}

An important determinant of economic and social progress is a good economic status of women in the labour market and the reduction or complete closing of the gender gap in earnings.

Economic independence is the key precondition which offers the possibility for both genders to make their own choices and have control over their life, and the main way to achieve it is through the acquisition of earnings.

Work legislation in most market economies today guarantees equal remuneration for work of equal value, but nevertheless, the presence of the gender gap in wages is more than obvious and common. Difference in earnings between men and women is one of the most common forms of discrimination in the labour market, in addition to discrimination in employment, professional advancement and others.

According to Samuelson and Nordhaus (1992) the phenomenon of discrimination is explained by differences in earnings arising from personal characteristics such as gender, race or religious affiliation.

Gender pay gap is usually a result of breaking the principle of equal pay for work of equal value, which is under the presumption that the same work operated by different genders requires the same level of responsibility, expertise, experience and readiness in the intellectual and physical sense.

Convention no. 100, adopted in 1951 by the International Labour Organization (ILO) strictly stipulates the prohibition of all forms of discriminatory behaviour in the provision of remuneration for work in terms of gender. This convention has been ratified in 2006 by more than 160 countries worldwide. It established the obligation of every state to establish such system (through legislation and/or collective agreements) to prevent any attempt of different remuneration of women and men for work of equal value. This principle is considered one of the most important international principles in the effort to establish gender equality worldwide.

\section{LITERATURE REVIEW}

The gender division of labour has a long tradition and contributes to the creation of the gap in earnings. Theoretical analysis of the origin of the gender gap payment is based on a combination of several theories (theories of labour market segmentation, theory of human capital, theory of competition, the idea of a dual labour market etc.). According to Blau and others (2000) there are three economic theories which can explain the causes of discrimination in the earnings. The first is the human capital theory that interprets differences in earnings as the differences in the level of education and level of experience of staff, then the theory of the reserve army of labour force and the theory of the division of the labour market on two sectors. According to Figart (1999) discrimination is the cause of unexplained components contained in the difference in pay between men and women.

Members of neoclassicism have found explanation of the gender pay gap in low levels of investment in human capital. On the other hand, members of feminist economic orientation have the thesis that the difference in earnings between the genders is the result of a number of non-market and institutional factors, as well as the segmentation of the labour market. 
When it comes to the economic dimension of the gender gap expressed by differences in earnings, it can be said that the literature related to the Western Balkans is very scarce. There are only two studies that approach this problem from the aspect of comparative analysis between the countries of the Western Balkans, and also only a dozen studies that approach this problem from the aspect of the individual countries of the Western Balkans. There is also a paper which compares the gender gaps in earnings in Serbia, Macedonia and four other countries in the Eastern Europe and Central Asia (Kazakhstan, Moldova, Tajikistan and Ukraine) (Blunch, 2010).

Blunch and Sulla (2010) were focused on labour market transitions and wages in Serbia. They have examined the incidence and nature of the gender earnings gap in Serbia and five other former socialist countries from Eastern Europe and Central Asia.

There is only a small number of studies in the area of the Balkan countries with valuable results, partly due to the fact that most are based on scarce, low quality data. Lack of sophisticated data and available official statistics is still the problem for demystification of gender gap in the region. Gender gap in earnings is mainly expressed as a percentage of average female wage in the average male earnings. In case of Serbia and other Balkan countries, the average salary is not the best solution for the representation of the distribution because of its non-normality, for the most of the countries in the region that problem is solved by using the median as an indicator of earned wages.

Data relating to the labour market of Serbia and the majority of the countries in the region indicate that most of the female labour force is concentrated in the so-called "traditional" industries and these are industries in which the gender pay gap is significantly higher than the mentioned average, which contributes to the assertion that "average" gender pay gap is not the best indicator of economic inequality between women and men.

Krstic and Reilly (2000) applied the Blinder-Oaxaca decomposition model to the data of Labour Force Survey for the period 1995-1998 and this paper is considered as one of the earliest papers which included one of the countries from Western Balkans (found at Avlijaš et al., 2013). The study showed that the unadjusted gender pay gap (per hour) grew in this period (from $10.1 \%$ in 1995 to $14.8 \%$ in 1998), but this increase was not statistically significant. Explained part of the gender gap had a negative sign, and recorded a decrease of 0.6 percentage points in 1995 and -1.2 per cent in 1998. In other words, it meant that working women have better performance compared to working men in the labour market. Unexplained part of the gender gap has a positive sign and an upward trend, with 10.7\% (1995) at 16.1\% (1998).

Kecmanović and Barrett (2011) analysed the gender pay gap based on data from the Labour Force Survey Serbia for the period 2001-2005. "Basic" model included only the education, work experience and region as predictors, while "comprehensive" model in addition to basic predictors included the employment sector and type of ownership (found at Avlijaš et al., 2013). The analysis also used Blinder-Oaxaca decomposition complemented by quantile regression. The analysis showed that the average unadjusted gap narrowed in 2005 to $5.4 \%$, compared to 2001 when it stood at $14.4 \%$. At this level (in 2005) it was lower than the average gender gap in others Eastern and Western economies. Unexplained part of the gap also had a downward trend (from $17.2 \%$ in 2001 to $10.5 \%$ in 2005), indicating a reduced impact of discrimination during these years. Explained part of the gender gap has decreased in the same period. In all observed years, explained part of the gender gap was smaller at the upper end of the wage distribution, while the unexplained part of the gap was greater, indicating the presence of the glass ceiling effect, and that women on the upper ends of the distribution of earnings, on 
average, even more qualified than men, suffer the effects of discrimination when it comes to earnings.

Several articles used quantile regressions or rather mean regressions to investigate the gender wage differential in transition countries (Adamchik and Bedi, 2000; Newell and Reilly, 2001; Falaris, 2004) and in particular on Serbian labour market (Krstić and Reilly, 2000; Lokshin and Jovanovic, 2003; Krstić et al. 2007; Ognjenović, 2009).

Reva (2012) dealt with the analysis of women in the labour market of Serbia (found at Avlijaš et all, 2013). The basis of the analysis was limited to application of Blinder-Oaxaca decomposition on monthly wages in order to explain the position of women in terms of employment, unemployment and the gender wage gap. The paper used Labour Force Survey data from April 2008 and October 2009.

Certainly the most comprehensive studies dealing with gender-based analysis of payments gap and comparative display between Serbia, Macedonia and Montenegro, is the project "Gender pay gap in the Western Balkans: located in Serbia, Montenegro and Macedonia ", implemented in 2012, based on data from the Labour force Survey for the period 2008 to 2011. Research team has measured the extent and characteristics of the gender gap payments for all three countries individually and performed a comparative analysis of trends observed gender pay gap between three countries. The analysis included the change of gender payment gap due to the economic crisis. Blinder-Oaxaca decomposition was applied to the Mincer's regression of wages, but also Heckman's model of selection that indicates the self-selection effects on childbearing payments gap.

Rokicka and Ruzik (2010) in their works dealt with the analysis of the gender wage gap in the informal economy. The specificity of this sector, which is reflected in the absence of the prescribed minimum wages, working conditions and working hours, significantly and negatively influences the position of employed women. Gander pay gap according to research by these authors was particularly evident at the bottom of the wage distribution.

\section{THE METHOdOLOGICAL FRAMEWORK OF THE RESEARCH}

For the purposes of modelling, we have used using data collected through the Survey on Income and Living Conditions - EU-SILC for 2014. This is the most relevant instrument to monitor poverty, inequality, social inclusion and living standards.

EU-SILC survey includes information on the territory of the Republic of Serbia as a whole and individually relevant data for each region at the NUTS (Nomenclature of Territorial Units for Statistics) 2 level (Belgrade, Vojvodina region, region of Šumadija and Western Serbia and the region of Southern and Eastern Serbia). Data relating to the region of Kosovo and Metochia were not available.

The basic sample framework consists of all households and all persons on the territory of the Republic of Serbia, except persons living in collective households and homeless people. The survey included a stratified, rotating and panel sample without replacement. The sample stratification was done according to the type of settlement and the territory at the level of NUTS 2.

The questionnaire included data on admission and economic activities of all household members in the sample who were 15 or more years old until the date December 31th, 2013. In total there was 17187 persons: 8280 men and 8907 women. 
The Mincer earnings function according to which individuals' earnings are the function of the achieved level of education and work experience, served as the basis for analysis of the factors that determine the formation of wages and verify the thesis that gender is a statistically significant variable affecting the variation in net earnings (logarithmic value) as the dependent variable. According to the theory of human capital, education is a process analogous to investment in physical capital. See Mincer (1974), Mincer, J., Polachek, S. (1974), Mincer, J., Polachek, S. (1978), Heckman et al. (2006), and Lemieux (2006) for background information on The Mincer earning function.

Form of earnings as a function of human capital is presented as follows:

$$
\ln y=\beta_{0}+\beta_{1} s+\beta_{2} x+\beta_{3} x^{2}+u
$$

$y$ - monthly earning of an employee in their main job

$s-$ level of education

$x$ - years of experience in paid jobs

$u$ - random error of regression representing unexplained factors of earnings.

In this way, presented form of earnings equation was extended with set of additional variables such as gender, ownership of companies in which the individual is employed, hours worked per week and the age of the employee (see Table 1).

The analysis included 1891 people and list of variables is presented in Table 1. Variables such as sectors of activity in which respondents work and occupation were excluded from the analysis because of incomplete data.

Table 1 List of variables used in the model

\begin{tabular}{ll}
\hline Name of variable & Coding \\
\hline Dependent variable & \\
The logarithmic value of the net monthly salary of the employee & \\
Independent variables & Female $=1$ \\
Gender & Male $=0$ \\
& Ratio \\
Age & Secondary education $=1$ \\
Highest education: secondary education & Else $=0$ \\
& Tertiary education $=1$ \\
Highest education: tertiary education & Else $=0$ \\
& Ratio \\
Years of working experience & Public sector $=1$ \\
Person is employed by public sector & Others $=0$ \\
Person is employed by private sector & Private sector = 1 \\
Hours of work during the week & Others $=0$ \\
\hline
\end{tabular}

Source: Authors.

The survey data used in in this study were not adequate for determining the size of the gender gap in earnings because the large number of respondents did not provide the information about the wage size. Therefore only the existence of gender pay gap could have been analysed. Problems related to the collection of data relevant for insight into the gender differences on the labour market and insight into the existing structure of the 
workforce is enormous obstacle for research endeavours dealing with this issue in most of the Balkan countries.

Regression model was estimated by the method of least squares. Individuals with extremely low or high earnings were excluded from the analysis. Preliminary analysis was conducted in order to satisfy the assumptions of linearity and normality, and absence of autocorrelation, multicollinearity and heteroscedasticity. From the analysis are excluded variables such as tertiary education (none of the respondents who gave information on the monthly earnings belonged to this category), private property company in which the employee is subject and work experience variables measured in years (due to the demonstrated multicollinearity).

\section{RESULTS}

The regression model which represents the influence of selected variables on formation of net earnings is presented in Table 2.

Dependent variable: Logarithm of net earnings

Table 2 Regression model

\begin{tabular}{lcrr}
\hline Independent variables & Coefficient & $\begin{array}{c}\text { Standardized } \\
\text { Coefficients (Beta) }\end{array}$ & p-value \\
\hline Constant & 4.315 & -0.21 & 0.000 \\
Gender & -0.068 & 0.10 & 0.000 \\
Age & 0.001 & 0.12 & 0.000 \\
Secondary education & 0.052 & 0.26 & 0.000 \\
Employed by the company in public ownership & 0.085 & 0.09 & 0.000 \\
Hours worked per week & 0.001 & $\mathrm{R}^{2}$ & 0.000 \\
\hline The mean value of the dependent variable & 4.456 & Adjusted R & 0.154 \\
The standard deviation of the dependent variable & 0.158 & $\mathrm{~F}_{(6,1885)}$ & 0.152 \\
Sum of squared residuals & 40.142 & $\mathrm{p}$-value (F) & 68.826 \\
The standard error of regression & 0.146 & 1.768 & 0.000 \\
Durbin-Watson & & & \\
\hline
\end{tabular}

Source: Author's calculation.

The coefficient of determination $\left(\mathrm{R}^{2}\right)$ whose role is to point out how much of the variance of the dependent variable (the logarithmic value of net earnings) explains the model is 0.154 or $15.4 \%$. Adjusted coefficient of determination (Adjusted R Square) is 0.152 , or $15.2 \%$. It provides the better assessment of the actual value of the coefficient of determination in the population. Low coefficient of determination indicates the importance of other, non-economic factors. According to ANOVA, the model is statistically significant $\left(\mathrm{F}_{(6,1885)}=68.826 ; \mathrm{p}<0.005\right)$.

The highest standardized coefficient beta is related to the variable employed by the company in public ownership (0.26) and variable gender $(-0.21)$, which means that these variables are the largest contributors to explanation of the variation in the dependent variable (the logarithmic value of net earnings), when subtracting the variance explained by other variables in the model. 
What is important to indicate is that the standardized regression coefficient on the variable gender is negative (-0.068), which indicates that the females earn less than males in Serbia. All other statistically significant predictor variables included in the model have a positive sign, which brings us to the conclusion that they have positive influence on the dependent variable.

\section{CONCLUSION}

Regression analysis has confirmed the presence of the gender pay gap and the impact of gender on the formation of wages in the context that females earn less than males. Due to the inadequacy of the available data and the inability to obtain relevant results, it was not possible to determine the height of gender gap in earnings, nor its decomposition.

Removing barriers in the way of closing the gender gap in the labour market and the establishment of equality between the genders is a perpetual struggle that requires above all a change of consciousness of public opinion and their attitudes.

For better understanding of the nature of gender pay gap it is necessary to examine the connection that gander pay gap has with systemic discrimination. Namely, it is necessary to explore whether the differences in the level of fees between genders for work of equal value, exist. If the statistics indicate the presence of differences in the amounts of wages for performing the same or two different jobs of equal value, the employer has to prove that this difference in fees is not due to gender discrimination. The fact is that the unadjusted gender gap in earnings in Western Balkan countries is lower than in Western countries and it is a consequence of the low representation of women (especially those with low skills) in the labour market in these countries. In other words, the higher the gap in employment, the lower unadjusted wage gap, and vice versa, as a rule, the biggest gap in employment occurs among those with the lowest qualifications. When more women with low qualifications enter the labour market, we can expect that the unadjusted pay gap will increase.

Women with low qualifications are absent from the labour market due to significantly low opportunity costs. In other words, it is economically unprofitable for them to be employed when low salaries or in many cases minimum wage cannot adequately compensate for the cost of running the household. The reasons for low opportunity costs should be sought, and also the influence of remittances from foreign countries in many cases. The main obstacle for more comprehensive analysis of phenomena is the lack of reliable and representative data, not only in Serbia but also in the other countries of the Balkan region.

\section{REFERENCES}

Adamchik, V.A. \& Bedi, A.S. (2000). Wage differentials between the public and the private sectors: Evidence from an economy in transition. Labour Economics 7(2), 203-224.

Avlijaš, S., Ivanović, N., Vladisavljević, M., Vujić, S. (2013).Gender Pay Gap in Western Balkan Countries: evidence from Serbia, Montenegro and Macedonia. Beograd: FREN.

Blunch, N. H. (2010). The Gender Earnings Gap Revisited: A Comparative Study for Serbia and Five Countries in Eastern Europe and Central Asia. Background paper commissioned by the World Bank's Poverty Reduction and Economic Management Unit, Europe and Central Asia Region Department.

Blunch \& Sulla (2010). The Financial Crisis, Labor Market Transitions and Earnings Growth: A Gendered Panel Data Analysis for Serbia. Background Paper, Poverty Reduction and Economic Management Unit, Europe and Central Asia Region Department, Washington, DC: World Bank. 
Blau, F. D \& Kahn, L. M. (2000). Gender Differences in Pay. Journal of Economic Perspectives 14(4), 75-99. Falaris, M.E. (2004). Public and private sector wages in Bulgaria. Journal of Comparative Economics 32, 56-72. Heckman, J. J., L. J. Lochner, \& P. E. Todd (2006). Earnings Functions, Rates of Return and Treatment Effects: The Mincer Equation and Beyond in Handbook of the Economics of Education, ed. by E. A. Hanushek and F. Welch, New York: Elsevier, 307-458.

Lemieux, T. (2006). The "Mincer Equation”" Thirty Years after Schooling, Experience, and Earnings, in Jacob Mincer: A Pioneer of Modern Labor Economics, ed. by S. Grossbard, New York, NY: Springer, chap. 11, 127-145.

Kecmanović, M. \& Barrett, G. (2011). The Gender Wage Gap during Serbia's Transition. Comparative Economic Studies 53, 695-720.

Krstić, G. \& Reilly, B. (2000). The gender pay gap in the Federal Republic of Yugoslavia. Economic Thought 33, 191-213.

Krstić, G., Litchfield, J. \& Reilly, B. (2007). An anatomy of male labour market earnings inequality in Serbia 1996-2003. Economic Systems 31, 97-114.

Lokshin, M. \& Jovanović, B. (2003). Wage differentials and state-private sector employment choice in Yugoslavia. Economics of Transition 11, 463-491.

Newell, A. \& Reilly, B. (2001). The gender pay gap in the transition from communism: Some empirical evidence. Economic Systems 25(4), 287-304.

Mincer, J. (1974). Schooling, Experience and Earnings. New York: Columbia University Press.

Mincer, J. \& Polachek, S. (1974) Family investments in human capital: Earnings of women, Journal of Political Economy, 82(2), pp. 76-108.

Mincer, J. \& Polachek, S. (1978) Women's earnings re-examined, The Journal of Human Resources 13(1), pp.118-134.

Ognjenović, K. (2009). Quantile regression analysis of female earnings in the private and public sectors in Serbia: Some evidence from survey data. Belgrade: Mimeo.

Reva, A. (2012). Gender Inequality in the Labor Market in Serbia (Poverty Reduction and Economic Management Unit, Europe and Central Asia Region Department Policy Research Working Paper No. 6008). Washington, DC: World Bank.

Rokicka, M. \& Ruzik, A. (2010). The Gender Pay Gap in Informal Employment in Poland (CASE Network Studies and Analyses No. 406). Warsaw: Center for Social and Economic Research. Retrieved March 30, 2012. from http://www.caseresearch.eu/sites/default/files/publications/30664403_CNSA_406_0.pdf

\section{PRIMENA MINSEROVE REGRESIJE ZARADA U ANALIZI RODNOG PLATNOG JAZA U SRBIJI}

Značajna odrednica ekonomskog $i$ društvenog progresa jeste dobar ekonomski status žena na tržištu rada i redukcija ili potpuno zatvaranje rodnog jaza u zaradama. Rodni jaz u zaradama predstavlja jedan od najvažnijih indikatora koji ukazuje na stepen pristupa žena ekonomskim mogućnostima i njegovo prisustvo svrstava se u najpostojanije osobine tržišta rada. Kršenje principa jednakosti i jednakih mogućnosti za žene i muškarce smatra se kršenjem osnovnih ljudskih prava pojedinca. Kao rezultat toga proizilaze značajni gubici u ekonomiji zemalja poput poslovnih gubitaka i propuštene ekonomske dobiti uzrokovane nepotpunom iskorišćenošću raspoložive radne snage. Ukoliko nema ekonomske samostalnosti, sve druge mere koje se preduzimaju radi poboljšanja položaja žena u društvu uopšte, imaju mnogo manje uspeha i uticaja. Cilj ovog rada je da odredi da li su prisutne razlike u zaradama između muškaraca $i$ žena. Minserova jednačina zarada prema kojoj je zarada pojedinaca funkcija dostignutog nivoa obrazovanja i radnog iskustva, posluzila je kao polazna osnova za analizu faktora koji određuju formiranje zarada i proveru teze da je pol statistički značajna varijabla koja utiče na varijacije neto zarada kao zavisne promenljive. Analiza je izvršena nad podacima prikupljenim putem Ankete EUSILC za područje Srbije u 2014. godini. Izgrađen je regresioni model koji je potvrdio prisustvo rodnog jaza u zaradama i uticaj pola na formiranje zarada u kontekstu da ženski pol zarađuje manje u odnosu na muški. Usled neadekvatnosti raspoloživih podataka nije utvrđena visina rodnog jaza u zaradama, niti je vršena njegova dekompozicija.

Ključne reči: rodni jaz u zaradama, tržište rada, regresioni model, EU-SILC. 